\title{
Investigating Factors Influencing Girls Participation in Science and Technology Education in Nigeria
}

\author{
Ndirika Maryann C. $\mathrm{PhD}^{1}$, Agommuoh Patience C. $\mathrm{PhD}^{2}$ \\ Department of Science Education, Michael Okpara University of Agriculture, Umudike.
}

\begin{abstract}
This study set out to investigate factors influencing female participation in science and technology in Nigeria. Five research questions were posed and one null hypothesis was set for analysis. Forty one science education students in Michael Okpara University of Agriculture, Umudike were the subjects of this study. Survey design was utilized. A 19-item questionnaire adapted by the researcher served as instrument of data collection. Research questions were analysed with mean and t-test was used to analyze the hypothesis. Results show that home, school and society are important factors influencing female participation in science and technology in Nigeria. The aspects of Females being saddled with lot of domestic chores, intimidation of girls by boys, gender stereotyping in science and scarcity of female models in science and technology are noted in this study. Based on the findings, recommendations are made among which is the need for parents to distribute domestic chores equally between boys and girls at home to enable girls to have enough time to study at home so they can delve into science and technology.
\end{abstract}

\section{Introduction}

Although there has been a lot of concern expressed by science educators, globally, on the need for more female participation in science there still is a somewhat silent but prevalent notion that science, especially the physical sciences is male domain. Low participation of females in the sciences cuts across every level of education. Science education is very vital to any nation's development and no citizen deserves exclusion or limitations in being scientifically literate. Nigeria, like other African nations has a dire need to rise up to ensure equality in participation of both its male and female citizens in science and technology education.

While the Nigerian government has in recent years focused attention on strengthening national capacity in science and technology - a key recommendation and objective of its Vision 20:2020 plan for economic transformation - it has not fully recognized the importance of gender equity in science education and has not initiated national policies toward this goal. Female participation in science received mention in Nigeria's most recent Science, Innovation, and

Technology Policy, but no specific objectives and strategies have been developed. This, in part, is due to a lack of awareness in Nigeria of the problem of the science gender gap and the importance of girls' and women's participation in science. Education for all understood in terms of equal access to education is not enough. Equality and the future development of societies are dependent on providing a high quality science education for all (Ekine \& Abay, 2013).

In the United Nations Millennium Declaration, member countries avowed to promote gender equality and the empowerment of women, as effective ways to combat poverty, hunger and disease and to stimulate development that is truly sustainable (UN Resolution, 2000). Although progress is being made to increase women's participation in many fields, UNESCO figures reveal that women make up a minority of the world's science researchers. In 121 countries with available data, women make up 29 percent of science researchers (UNESCO Institute of Statistics, in Ekine and Abay, 2013). Throughout the world, women continue to be significantly underrepresented in every sector of science, technology, engineering and mathematics (STEM). Men outnumber women as students, educators, researchers, and workers in these fields. While the number of women enrolling in higher education is increasing rapidly in many countries and in some has surpassed male enrollment, men significantly outnumber women in science and engineering disciplines (UNESCO, 2010).

A lot of factors have been identified for the lack of interest in science by women. Some of these, according to Akinsowon and Osisanwo (2014) include:

Individual Interest: This is a relatively stable individual motivational disposition towards specific objects of interest and is characterized by increased attention and (in most cases) positive effect and emotions. The object of interest could be concrete, a particular content, events, or ideas. Individual disposition towards interest is characterized by the tendency of individuals to re-engage with an object of interest and thus represents a relatively stable person- object relationship. Thus, in the science education context, interest in science represents a student's enduring disposition to engage in science school subjects (which represent the objects of interest, e.g., physics). 
Situational Interest; by contrast, is triggered by the environment, and is characterized by a state of actual attraction or curiosity as well as increased attention. Situational interest comprises two phases. The environment plays a larger role in making science interesting for women as various environmental factors could readily discourage girls and women, such as:

$>\quad$ The teachers' factor; the perceptions and attitude of teachers teaching in school may be discouraging; this attitude often makes girls to drop out of school. Teachers in some rural part of Africa believe that boys will go to university to take courses like medicine, engineering, architecture and so on, while girls will only study to become secretaries, teachers, designers and so on (Angeline, 2011). This perception or attitude of teachers inform how they teach and attend to the girls in classes especially mathematics and science, and these end up affecting the performance of the girl child. It is on record that one out of every three women in the world is illiterate, meaning that boys are more in the school than girls. There are also established facts that show that teachers' are more attentive to boys and offer them more opportunities for hands-on practical work while the girls are almost ignored or not given as much attention as the boys (UNESCO, 1999).

Even most of the textbooks used for STEM courses use boys as key figures for examples in depicting Science and Technology.

$>\quad$ The home factor; balancing family life and personal relationships while achieving a successful career in science is becoming a major challenge for women; this has made some women forgo advancements in their careers in order to devote time to raising a family. The challenges of child care and the demands of running a research laboratory are often seen as incompatible. Women who plan to have children in the future drop out of the academic research race at twice the rate of men. Women are hit hard with family responsibilities just when they need to meet research goals (Stephanie, 2013).

In view of this fact, it becomes expedient to investigate some of the factors which could influence female participations in science, thus the present study has a major purpose to investigate the influence of home, school and societal factors on female participation in science in Nigeria.

The study sought answers to the following research questions:

1. To what extent is female participation in science and technology influenced by home factors?

2. To what extent is female participation in science and technology influenced by school factors?

3. To what extent is female participation in science and technology influenced by societal factors?

4. To what extent is female participation in science and technology influenced by personal factors?

\section{Hypothesis}

$\mathrm{HO}_{1:}$ There is no significant difference between male and female students' perception of influence on female participation in science.

\section{Method}

The study utilized survey design. Forty one undergraduate science students in Michael Okpara University of Agriculture, Umudike, were the subjects of this study. Questionnaire was the instrument for data collection. The questionnaire comprised of 19 items with modified four scale, Likert-type Response mode of Very High Extent (VHE), High Extent (HE), Low Extent (LE), Very Low Extent (VLE). The questionnaire copies were distributed and collected on the spot. Data collated were analysed using mean and t-test. Mean was used to analyse the research questions using the following criteria: VHE = mean $\geq 3.00$; HE $=$ mean $2.50-2.99$; $\mathrm{LE}=2.00-2.49$ and VLE $=$ less than 2.00. t-test was used to test the hypothesis at 0.05 level of significance.

\section{Results}

Research Question 1: To what extent is female participation influenced by home factors?

Table 1: Responses of science students on extent of Influence of Home Factors on Female Participation in Science

\begin{tabular}{|c|c|c|c|c|}
\hline $\mathbf{S} / \mathbf{N}$ & Item Statement & Std. Deviation & Mean & Decision \\
\hline 1 & Girls are assigned more domestic duties in the house than boys & .844 & 3.29 & VHE \\
\hline 2 & Girls do not have adequate time to study in the house & .808 & 2.56 & HE \\
\hline 8 & $\begin{array}{l}\text { My parents advise me not to choose science and technology } \\
\text { courses as my future career }\end{array}$ & .613 & 1.22 & VLE \\
\hline 9 & $\begin{array}{l}\text { I do not get enough support from my parents to tackle } \\
\text { problems in science and technology }\end{array}$ & .746 & 1.51 & VLE \\
\hline
\end{tabular}

Table 1 shows that home factors, especially the aspect of girls not having enough time for study at home and having more domestic duties than boys influence their participation in science to a high extent and very high extent respectively. Parental influences are seen as having little to do with female participation in science. 
Research Question 2: To what extent is female participation in science and technology influenced by school factors?

Table 2: Responses of science students on extent of Influence of School factors on female participation in science

\begin{tabular}{|l|l|l|l|l|}
\hline $\mathbf{S}$ S/N & Item & Std. Deviation & Mean & Decision \\
\hline $\mathbf{1 0}$ & $\begin{array}{l}\text { Science and technology teachers do not encourage } \\
\text { girls to aspire for science and technology courses }\end{array}$ & .969 & 1.76 & VLE \\
\hline $\mathbf{1 1}$ & $\begin{array}{l}\text { Girls are usually intimidated in the class by boys } \\
\text { when girls perform better in science and technology } \\
\text { courses }\end{array}$ & 1.073 & 2.73 & HE \\
\hline $\mathbf{1 2}$ & $\begin{array}{l}\text { Science and technology teachers ask boys questions } \\
\text { more often than girls in the class }\end{array}$ & .750 & 2.29 & $\mathbf{L E}$ \\
\hline $\mathbf{1 3}$ & $\begin{array}{l}\text { I am not free to express my opinion in the science } \\
\text { class without fear of intimidation by boys }\end{array}$ & .872 & 1.88 & VLE \\
\hline $\mathbf{1 4}$ & $\begin{array}{l}\text { The science teacher acknowledges, encourages and } \\
\text { motivates boys more than girls }\end{array}$ & 1.000 & 2.00 & $\mathbf{L E}$ \\
\hline
\end{tabular}

Table 2 shows that the only school factor which influences female participation in science to a high extent is the intimidation in the class by boys when girls perform better in science and technology courses.

Research Question 3: To what extent is female participation in science and technology influenced by societal factors?

Table 3: Responses of science students on extent of Influence of Societal Factors on Female Participation in

\begin{tabular}{|l|l|l|l|l|}
\hline \multicolumn{2}{|l|}{ Science } & Std. Deviation & Mean & Decision \\
\hline $\mathbf{3}$ & Item & .870 & 2.51 \\
\hline $\mathbf{4}$ & $\begin{array}{l}\text { In my society girls are brought up with the notion } \\
\text { that the study of science and technology are for boys } \\
\text { and tough girls }\end{array}$ & $\begin{array}{l}\text { In my culture, women are regarded as weak and } \\
\text { incapable of aspiring for challenging courses like } \\
\text { science and technology }\end{array}$ & .989 & 2.15 \\
\hline $\mathbf{5}$ & $\begin{array}{l}\text { Women in science and technology are seen as } \\
\text { rebellious and too strong for men to marry }\end{array}$ & 1.129 & LE \\
\hline $\mathbf{6}$ & $\begin{array}{l}\text { Female models are seldom seen in science and } \\
\text { technology }\end{array}$ & .705 & 2.63 & LE \\
\hline $\mathbf{1 8}$ & $\begin{array}{l}\text { Many important scientists in my country are males, } \\
\text { so this means science and technology courses are } \\
\text { mainly for males }\end{array}$ & .794 & 1.66 & VLE \\
\hline
\end{tabular}

In Table 3, results show that societal gender stereotyping in science and scarcity of female models influence female participation in science to a high extent.

Research question 4: To what extent is female participation in science and technology influenced by personal factors?

Table 4: Responses of Science Students on Extent of Influence of Female Personal Factors on Female Participation in Science

\begin{tabular}{|l|l|l|l|l|}
\hline $\mathbf{S} / \mathbf{N}$ & Item & Std. Deviation & Mean & Decision \\
\hline $\mathbf{7}$ & I see science and technology courses as male subjects & 1.005 & 1.80 & VLE \\
\hline $\mathbf{1 5}$ & $\begin{array}{l}\text { Girls feel discouraged and often tend to admit that } \\
\text { boys are better than girls in science and technology } \\
\text { courses }\end{array}$ & 1.055 & 2.29 & LE \\
\hline $\mathbf{1 6}$ & $\begin{array}{l}\text { Girls believe they cannot study engineering or } \\
\text { mathematics or any technology course }\end{array}$ & .833 & 1.39 & VLE \\
\hline $\mathbf{1 7}$ & $\begin{array}{l}\text { Girls are weaker than boys and so cannot do tough } \\
\text { courses science and technology }\end{array}$ & .722 & 1.68 & VLE \\
\hline $\mathbf{1 9}$ & $\begin{array}{l}\text { I think the only science subject a woman can do well } \\
\text { is Biology }\end{array}$ & 1.061 & 1.78 & VLE \\
\hline
\end{tabular}

Table 4 indicates that all the listed items concerning personal female factors influence female participation in science to Very low extent.

Research Question 5: What are the mean differences in the responses of male and female science students on influence of home, school, societal and personal factors on female participation in science? 
Table 5: Mean Differences in the responses of male and female science students on influence of home, school, societal and personal factors on female participation in science

\begin{tabular}{|c|c|c|c|c|}
\hline & Gender & $\mathrm{N}$ & Mean & Std. Deviation \\
\hline \multirow[t]{2}{*}{ Q1 } & Male & 24 & 3.04 & .859 \\
\hline & Female & 17 & 3.65 & .702 \\
\hline \multirow[t]{2}{*}{ Q2 } & Male & 24 & 2.33 & .637 \\
\hline & Female & 17 & 2.88 & .928 \\
\hline \multirow[t]{2}{*}{ Q3 } & Male & 24 & 2.29 & .908 \\
\hline & Female & 17 & 2.82 & .728 \\
\hline \multirow[t]{2}{*}{$\mathrm{Q} 4$} & Male & 24 & 2.04 & .955 \\
\hline & Female & 17 & 2.29 & 1.047 \\
\hline \multirow[t]{2}{*}{ Q5 } & Male & 24 & 2.25 & 1.073 \\
\hline & Female & 17 & 2.18 & 1.237 \\
\hline \multirow[t]{2}{*}{ Q6 } & Male & 24 & 2.71 & .690 \\
\hline & Female & 16 & 2.50 & .730 \\
\hline \multirow[t]{2}{*}{ Q7 } & Male & 24 & 2.13 & 1.116 \\
\hline & Female & 17 & 1.35 & .606 \\
\hline \multirow[t]{2}{*}{ Q8 } & Male & 24 & 1.33 & .761 \\
\hline & Female & 17 & 1.06 & .243 \\
\hline \multirow[t]{2}{*}{ Q9 } & Male & 24 & 1.58 & .830 \\
\hline & Female & 17 & 1.41 & .618 \\
\hline \multirow[t]{2}{*}{ Q10 } & Male & 24 & 1.88 & .992 \\
\hline & Female & 17 & 1.59 & .939 \\
\hline \multirow[t]{2}{*}{ Q11 } & Male & 24 & 2.46 & 1.021 \\
\hline & Female & 17 & 3.12 & 1.054 \\
\hline \multirow[t]{2}{*}{ Q12 } & Male & 24 & 2.46 & .779 \\
\hline & Female & 17 & 2.06 & .659 \\
\hline \multirow[t]{2}{*}{ Q13 } & Male & 24 & 1.75 & .847 \\
\hline & Female & 17 & 2.06 & .899 \\
\hline \multirow[t]{2}{*}{ Q14 } & Male & 24 & 2.21 & 1.062 \\
\hline & Female & 17 & 1.71 & .849 \\
\hline \multirow[t]{2}{*}{ Q15 } & Male & 24 & 2.50 & 1.063 \\
\hline & Female & 17 & 2.00 & 1.000 \\
\hline \multirow[t]{2}{*}{ Q16 } & Male & 24 & 1.58 & 1.018 \\
\hline & Female & 17 & 1.12 & .332 \\
\hline \multirow[t]{2}{*}{ Q17 } & Male & 24 & 1.92 & .717 \\
\hline & Female & 17 & 1.35 & .606 \\
\hline \multirow[t]{2}{*}{ Q18 } & Male & 24 & 1.88 & .850 \\
\hline & Female & 17 & 1.35 & .606 \\
\hline \multirow[t]{2}{*}{ Q19 } & Male & 24 & 1.92 & 1.060 \\
\hline & Female & 17 & 1.59 & 1.064 \\
\hline
\end{tabular}

\section{Hypothesis}

$\mathrm{HO}_{1:}$ There is no significant difference between male and female students' perception of factors influencing female participation in science.

Table 5: t-test Analysis of Difference between male and female students' perception of Influence of Factors Influencing female participation in science.

\begin{tabular}{|l|l|l|l|}
\hline S/N & $\mathrm{t}$ & $\mathrm{df}$ & $\mathrm{p}$-value \\
\hline Q1 & -2.478 & 38.110 & $0.018^{*}$ \\
\hline Q2 & -2.113 & 26.426 & $0.044^{*}$ \\
\hline Q3 & -2.078 & 38.325 & $0.044^{*}$ \\
\hline Q4 & -.789 & 32.547 & 0.436 \\
\hline Q5 & 0.198 & 31.410 & 0.844 \\
\hline Q6 & 0.903 & 31.013 & 0.373 \\
\hline Q7 & 2.848 & 36.947 & $0.007^{*}$ \\
\hline Q8 & 1.652 & 29.200 & 0.109 \\
\hline Q9 & 0.758 & 38.863 & 0.453 \\
\hline Q10 & 0.932 & 39 & 0.357 \\
\hline Q11 & -2.000 & 33.913 & $0.054^{*}$ \\
\hline Q12 & 1.772 & 37.681 & 0.084 \\
\hline Q13 & -1.110 & 33.281 & 0.275 \\
\hline Q14 & 1.680 & 38.355 & 0.101 \\
\hline Q15 & 1.536 & 35.829 & 0.133 \\
\hline Q16 & 2.090 & 29.475 & 0.045 \\
\hline Q17 & 2.717 & 37.683 & $0.010^{*}$ \\
\hline Q18 & 2.295 & 38.990 & $0.027^{*}$ \\
\hline Q19 & 0.975 & 34.525 & 0.336 \\
\hline
\end{tabular}

* Significant at 0.05 level of Significance , Table 5 shows that mean differences in male and female responses are significant for items; $1,2,3,7,11,17 \& 18(\mathrm{p} \leq 0.05)$. Thus for these items, HO1 is rejected. 


\section{Discussion}

Results of this study show that home factors pose a great deal of influence on female participation in science especially with respect of time availability for home studies by female students. This is in line with the findings of Lewis and Lockheed, 2006 in Ekine and Abay (2013). This could probably be a major reason why many females shy away from the sciences due to the intensive study they involve. They may tend to opt for subjects that may not require a lot of time studying them.

School factors are also revealed in this study as influences on female participation in science. The study reveals a high extent of influence of school factor, especially the classroom intimidation faced by girls from boys in science classroom (item 11, Table 2). Moreover the mean responses to this effect from females are higher than the males (Table 4, Q11) and table 5 shows a significant difference in male and female responses for this item. Intimidation by males in science classes when females perform better goes to confirm the unacceptable popular notion that science is male domain.

The society is also shown in this study to exert an influence on female participation in science to a high extent especially with respect to gender stereotyping and scarcity of female models in science and technology in our society. This finding aligns with that of Ekine and Abay (2013) who reported a similar observation as a reason for low female participation in science in our country. Many young girls may thus tend to view science as male subject and reserved for only exceptionally tough females.

\section{Conclusion And Recommendations}

This study has revealed that home, school and society are important factors influencing female participation in science and technology in Nigeria. The aspects of Females being saddled with lot of domestic chores, intimidation of girls by boys over girls in science classes when girls do better, gender stereotyping in science and scarcity of female models in science and technology are noted in this study. Based on the findings, the following recommendations are made:

1. Parents should distribute domestic chores equally between boys and girls at home

2. Parents should start early to dismiss the prevalent notion among their children that science is too tough for girls

3. Science teachers should be more sensitive to activities of their students in the classroom and motivate girls who perform well in science.

4. Authors of science textbooks should maintain gender equity in the examples they cite and role models they portray

5. Female models in science and technology should encourage and groom young girls into science and technology.

\section{References}

[1]. A. O. Ekine and N. A. Abay, Enhancing girls' participation in science in Nigeria. 2013. www.cssia.org/pdf/20000193. Retrieved January $14,2017$.

[2]. United Nations General Assembly, Resolution. United Nations Millennium Declaration, 2000. 55/2 http://www.un.org/ millennium/declaration/ares552e.htm. Retrieved on January 14, 2017.

[3]. UNESCO . Women's and Girls' Access to and Participation in Science and Technology Paris, France: 2010. UNESCO, 2

[4]. A. O. Akinsowon and F. Y. Osisanwo, Enhaning interest in sciences, technology and mathematics (STEM) for the Nigerian folk. International Journal of Information Science, 4 (1), 2014, 8-12.

[5]. N. Angeline, Girls, schools and statistics education in South Africa, First Africa Young Statisticians conference,2011, [Online] Available: http://www.statssa.gov.za/ycs.

[6]. S. P. Stephanie, Science Gender Gap: Five Resons Women Trail Men In Science", Live Science 2013, [Online] Available:http://www.huffingtonpost.com/2013/03/07/science-gender-gap-five-reasons-women- men_n_2827567.html. 